\title{
Urgency of Mediator (Mediation) in Resolving Divorce Cases in Religious Courts
}

\author{
Dr. Muhammad Juni Beddu, Lc., MA¹, Fithri Mehdini Addieningrum, SHI., M.Hum², Neri Aslina, SHI., \\ MA $^{3}$, Dr. Nurliana, SHI., MA ${ }^{4}$, Dian Meliza, SHI., MA ${ }^{5}$, Dr. Syamsiah Nur, S.Ag., MHI ${ }^{6}$, Dr. Said \\ Maskur, M.AG ${ }^{7}$
}

${ }^{123}$ STAI Ibnu Sina Batam, ${ }^{4}$ STAI Diniyah Pekanbaru, ${ }^{5}$ Universitas Islam Kuantan Singinging, ${ }^{6}$ STAI Auliaurrasyidin Tambilahan Inhil Riau, ${ }^{7}$ IAI Ar-Risalah Guntung

1jhuni-cairo@yahoo.co.id, ${ }^{2}$ fitrimehdini@yahoo.co.id, ${ }^{3}$ neriaslina@yahoo.co.id, ${ }^{4}$ nurliana@ diniyah.ac.id, dianhabibi2011@gmail.com, ${ }^{6}$ syamsiah.nur@ stai-tbh.ac.id, ${ }^{7}$ said.maskur@gmail.com

_Article History: Received: 11 January 2021; Accepted: 27 February 2021; Published online: 5 April 2021

\begin{abstract}
This scientific paper was written to investigate the Urgency of Mediators in Resolving Divorce Cases in the Religious Courts. The descriptive method was employed to describe a scientific paper with a theoretical description. It can also be called a grand theory. A mediator is a person who should be able to divert the intention of the two parties from the one who wants to divorce to undo that intention. Therefore, the two parties in the case are settled peacefully. The mediator is the judge himself or an individual or institution that has been certified by the Supreme Court.
\end{abstract}

Keywords: Urgency, Mediator (Mediation), Divorce Cases, Religious Courts.

\section{INTRODUCTION}

The concept of dispute resolution in Islamic law is carried out using the Islah approach in various forms, such as Wilayat al-mazalim, al-hisbah, and takhim. Meanwhile, the alternative concept of dispute resolution in statutory regulations is carried out by consultation, negotiation, mediation, conciliation, expert judgment, and arbitration. However, it is also used in resolving divorce cases within the Islamic religious court itself. Mediation is one form of alternative dispute resolution. In the Indonesian legal system, mediation can be used to resolve disputes outside the court and disputes or cases that have been submitted to the court (court-annexed mediation) based on Supreme Court Regulation No. 1 of 2016.

Mediation as an alternative out-of-court dispute resolution mechanism has long been used in various cases of business, environment, labor, land, housing, and so on, which embodies community demands for fast, effective, and efficient dispute resolution (Bambang Sutiyoso, 2008). Mediation is dispute resolution involving a third party as an intermediary or mediating dispute resolution. Meanwhile, etymologically, the term mediation comes from Latin, "mediare" which means being in the middle. This definition refers to the role played by the third party as a mediator who is demanded to be in a neutral and impartial position in resolving disputes. The mediator is required to be able to maintain the interests of the disputing parties fairly and equally, thereby fostering the trust of the disputing parties (Syahrizal Abbas, 2009).

In principle, mediation is a way of settling disputes outside the court through negotiations involving neutral (non-intervention) and impartial third parties and their presence is accepted by the disputing parties. The third-party, called the mediator, has the task of assisting the disputing parties in resolving the problem but does not have the authority to make decisions (Bambang Sutiyoso, 2008). In mediation, a mediator plays a role in assisting the disputing parties by identifying the issues in dispute, developing options, and considering alternatives that can be offered to the parties to reach an agreement. In carrying out its role, the mediator only has the authority to provide advice or determine the mediation process in seeking dispute resolution. The mediator does not have the authority and decisive role in relation to the content of the dispute. The mediator only maintains how the mediation process can run, resulting in an agreement from the parties (Allan, 2004).

A more precise definition of mediation can be found in the Supreme Court Regulation Number 1 of 2008. Mediation is defined as a process of dispute resolution that is faster and cheaper and can provide greater access to the parties to find a satisfactory solution and fulfill a sense of justice. The integration of mediation into court proceedings can be an effective instrument to overcome the problem of case accumulation in court. Mediation is also strengthening and maximizing the function of the judicial institution in resolving disputes in addition to court processes that are decisive in nature. After evaluating the implementation of mediation procedures in court based on Regulation of the Supreme Court of the Republic of Indonesia Number 2 of 2003, it turns out that several problems stem from this Super Court Regulation. Therefore, the Supreme Court Regulation needs to be revised with a perspective to making more efficient use of mediation related to the litigation in court (Supreme Court Regulation No. 1 of 2008). 
The issue of divorce is a problem that is very much happening nowadays in the Religious Courts. Divorce files piled up guesswork every day on tables in almost all districts in all provinces in Indonesia. The Regulation of the Supreme Court of the Republic of Indonesia Number 1 of 2008 concerning Mediation Procedures in Courts stated that all cases currently not included in the exclusion criteria are required to undergo mediation in advance, including divorce cases in the Religious Courts. Divorce is defined as the abolition of marriage by a judge's decision or the demands of one of the parties in the marriage. Judging from the aspect of the perpetrator of the divorce, divorce is divided into two. The first one is divorce by the husband in which the husband divorce the wife. Second is legal divorce by the wife, in which divorce by the wife by submitting a divorce request to the Religious Court. Divorce by wife cannot occur before the Religious Court officially decides, based on the recapitulation of case reports submitted to the Religious Courts.

Indonesia positive law criminal cases cannot be resolved out of court in nature. However, in certain cases, it is possible to settle cases out of court. Furthermore, law enforcement practices in Indonesia often involve criminal cases being resolved out of court through the discretion of law enforcement officials, peace mechanisms, customary institutions, and so on (Supreme Court Regulation No. 2 of 2012). Currently, there is no formal legal basis in the implication of the practice of settling cases outside the court. Therefore, it is also common for cases to have informal settlements through customary law mechanisms. However, they are still processed in court according to the applicable positive law. The consequence of the increasingly applied existence of penal mediation as an alternative to the settlement of cases in the field of criminal law through restitution in the criminal process shows that the difference between criminal and civil law is not that big and the difference becomes non-functional (cf: http://pn-kepanjen.go.id).

Mediation, if applied effectively, is certainly very beneficial for the parties in dispute, especially in divorce cases, because with the realization of this, the judiciary indirectly also helps in realizing the goal of a sakinah, mawaddah, warohmah, and eternal marriage. However, these efforts need to be evaluated and corrected when the fact is that lawsuit case at the Pekanbaru Religious Court which was attempted to be resolved amicably with the help of a mediator has not been effective (Nita Nurvita, 2016).

\section{RESEARCH METHODS}

The research methodology is a design or research design. This design contains a formulation of the object or subject to be studied, data collection techniques, data collection and analysis procedures with regard to a particular problem focus. Research methods are "the methods used by researchers in designing, implementing, processing data, and drawing conclusions with respect to certain research problems" (N. S. Sukmadinata, 2008). Descriptive research is a research method aimed at describing existing phenomena, which are taking place at present or in the past. According to Furchan, descriptive research has the following characteristics: First, descriptive research tends to describe a phenomenon as it is by examining regularly, prioritizing objectivity, and being carried out carefully. Second, there is an absence of treatment that is given or controlled and the absence of the h-test (A Furchan, 2004). Meanwhile, Ronny Kountur suggests that descriptive research has the following characteristics: First, it is related to the current situation. Second, it describes things one by one. Third, the variables studied are not manipulated or there is no treatment (Ronny Kountur, 2003).

The research method used in this study was descriptive research with a qualitative approach. In this study, a qualitative approach is defined as a type of research in which the findings are not obtained through statistical procedures or other forms of calculation. According to Saifuddin Azwar, a qualitative approach is an approach in which analysis emphasizes the deductive and inductive inference processes, as well as on the process of analyzing the dynamics of the relationship between observed phenomena using scientific logic (Saifuddin Azwar, 2005). Qualitative research conducts research in natural settings or the context of an entity. This is done because the natural ontology requires the existence of facts as a whole that cannot be understood if separated from context (Yvonna S. Lincoln and Egon G. Guba, 1985).

Such an approach focuses on reasoning based on social reality objectively and through a phenomenological paradigm. It means that this method is used for three considerations, namely to facilitate the understanding of multiple realities, to present intrinsically between the researcher and reality, and more sensitive and can adjust to the value-form used (Lexy J. Moeloeng, 2000). A qualitative approach is used based on the consideration if there are several realities that make it easier for researchers to carry out their studies. Furthermore, this approach makes the sharpening of the influence and value patters to be more sensitive to adjust.

\section{RESULTS AND DISCUSSION}

Mediation is a form of consensus alternative dispute resolution. Etymologically, mediation comes from the Latin language of "mediare" which means in the middle or "being in the middle" because the person who is mediating (mediator) is required to be in the middle or mediate the person in dispute. In terms of terminology (terms), there are many opinions regarding the meaning of mediation, where the definitions of mediation are as follows: Mediation is the process of negotiating dispute resolution or problem-solving in which impartial third parties work together with the disputing parties to help obtain a satisfactory agreement (Susanti \& Adi, 2008). In other literature, 
mediation is a process where parties with the help of a person or several people systematically resolve disputed problems find alternatives, and reach solutions that can accommodate their needs (Rachmat Syafaat, 2008).

According to Syahrial Abbas, as quoted by Rahmad, he explained that, from the side of legitimacy, mediation emphasizes the existence of a third party (mediator) who can handle the disputing parties to resolve their disputes. This explanation is very important in order to differentiate it from other alternative forms of dispute resolution (Rachmat Syafaat, 2008). Regarding what is meant by mediation, it can be found in the Supreme Court Regulation No.01 of 2008, Article 1 paragraph (7), in which "mediation is a method of dispute resolution through the negotiation process to obtain an agreement between the parties assisted by the mediator" (Supreme Court Regulation No.01 of 2008). From the provisions regarding the definition of mediation, it can be concluded that mediation is a process of finding the best solution to bring the parties to an agreement, where the agreement is obtained and gets the approval of the disputing parties without any intervention from the mediator.

Regarding the implementation of mediation, it has been regulated in the following laws:

a. HIR Article 130/Article $154 \mathrm{RBg}$ (Civil Code)

1) If on that appointed day, both parties have not arrived, the district court with the help of the chairman tries to reconcile the dispute parties.

2) If such reconciliation can be achieved, at the time of the hearing a letter (Acta van vergelijk) is made regarding it in which both parties are punished to keep the agreement made and the letter is binding and will be carried out as an ordinary decision.

3) Such a decision is not permitted to be appealed.

4) During the reconciliation process of the two parties, it is necessary to use an interpreter then the following rules are followed that:

b. Chapter X VII Civil Code concerning Peace articles $1851-1864$.

c. Government Regulation Number 9 of 1975 Article 32.

If reconciliation is reached, then a new lawsuit cannot be filed based on reasons that existed before the reconciliation and were known to the plaintiff at the time the reconciliation is reached.

d. Law No. 7 of 1989 concerning the Religious Courts, which was amended by Law No. 50 of 2009 concerning the Religious Courts.

e. Supreme Court Circular No. 01 of 2002 concerning Empowerment of First Level Courts to Implement Peaceful Institutions, which was later revised by Supreme Court Regulation No. 02 of 2003 concerning Mediation Procedures in Courts, which was further refined by Supreme Court Regulation No. 01 of 2008 concerning Mediation Procedures in Courts (Supreme Court Regulation No. 01 of 2008 Article 9 paragraph (3)).

The procedures and stages of mediation (Karmuji, 2016) in court are regulated in Article 3 to Article 4 of the Supreme Court Regulation No. 02 of 2003 concerning Mediation Procedures in Courts (Syahrizal Abbas, 2009). Mediation at the District or Religious Courts is divided into two stages, namely the pre-mediation stage and the mediation implementation stage. The pre-mediation stage is the stage where the parties get an offer from the judge to use the mediation and the parties appoint a mediator as a third party who will help resolve the dispute (Syahrizal Abbas, 2009).

Kovach in Suyud Margono divided the mediation process into nine stages as follows:

a. Initial setup or arrangement,

b. Introduction or preamble by the Mediator,

c. Opening statement by the parties,

d. Information gathering,

e. Identification of problems, agenda-setting, and caucuses,

f. Generating problem-solving options,

g. Negotiation

h. Deal

i. Closing (Suyud Margono, 2004).

The mediation procedure is a stage of the mediation process. There are several mediation procedures carried out in court in accordance with Supreme Court Regulation No. 01 of 2008, namely the pre-mediation stage, and the mediation process stage.

1. Pre-Mediation Stage

a. On the day of the predetermined hearing which is attended by both parties, the judge obliges the parties to fulfill mediation.

b. The absence of any of the party's co-defendants does not prevent the mediation from being carried out.

c. Judges, through their attorneys or directly to the parties, encourage the parties to take a direct or active role in the mediation process.

d. The attorney for the parties is obliged to encourage the parties themselves to play a direct or active role in the mediation process.

e. The judge is obliged to postpone the trial process of the case to provide an opportunity for the parties to take the mediation process. 
f. The judge is obliged to explain the mediation procedure in this Supreme Court Regulation to the parties in dispute.

2. Mediation Process Stage

a. Within a maximum period of 5 (five) working days after the parties appoint the agreed mediator, each party can submit case resumes to each other and the mediator.

b. Within a maximum period of 5 (five) working days after the parties fail to select a mediator, each party may submit a case resume to the appointed mediator judge.

c. The mediation process lasts a maximum of 40 (forty) working days since the mediator is selected by the parties or appointed by the chairman of the panel of judges as referred to in article 11 paragraph (5) and (6).

d. Based on the agreement of the parties, the mediation period may be extended by no later than 14 (fourteen) working days from the end of the 40 (forty) days period as referred to in paragraph 3.

e. The duration of the mediation process does not include the period for case examination.

f. If necessary and based on the agreement of the parties, mediation can be carried out remotely using communication devices.

In the mediation stage, a mediator is required to hold the principles and behave that maintain his neutrality and impartiality as a mediator. There are several principles a mediator has to possess to maintain neutrality in handling a case:

a. Understanding the characteristics of yourself, something that makes you angry or freeze,

b. Paying attention to body style, to what extent feelings affect attitude,

c. Watching out for patterns of behavior that might lead to adversity,

d. Paying attention to the people you are interacting with,

e. Using neutral language,

f. Coming as a "new" person who wants to know everything, and

g. Taking a breaks when you feel necessary.

\section{CONCLUSION}

Mediation has a broader scope as long as humans interact with social life. There are two perspectives of conflict in each interaction, the public, and private matters. Conflicts in the public sphere are related to the public interest, where the State has an interest in defending the public interest (Syahrizal Abbas, 2009). This is different from private law which only deals with individuals. However, the dimensions and scope of both are broad. For example, private law has areas such as inheritance law, property law, family law, business law, contract law, and many others. Explanations in civil law or private law, the parties can resolve their case in a legal manner (court) or nonlegal manner. Meanwhile, the public jurisdiction which requires a crime and violation committed by a person has to be resolved legally. In a criminal case, the perpetrator of a crime or violation is prohibited to bargain (negotiate) with the State as the main guardian in protecting the public interest. In this kind of case, a criminal offender conflicts with the State and should not be able to negotiate and compensate the State.

Meanwhile, at the jurisdiction of each, typically in public and civil matters, the scope of mediation is concerned with personal or private matters. Family disputes, such as disputes over divorce, inheritance, marriage, contracts, banking, business, and various other cases, can be resolved through mediation.

Peaceful conflict (dispute) resolution has been practiced in Indonesian society for centuries. The Indonesian people feel that the peaceful settlement of disputes has led them to live in harmony, justice, and balance, as well as to maintain the values of togetherness (communality) in society. This pattern of life continues to be developed into a strong culture. The community strives to resolve disputes quickly and still upholds the values of togetherness (communality) and does not deprive or suppress the freedom of other individuals (Syahrizal Abbas, 2009).

Negotiation for consensus is the philosophy of the Indonesian people in making decisions, including in dispute resolution. Negotiation for consensus as a philosophical value of the Indonesian nation is incarnated in the basis of the State, namely Pancasila. In the fourth principle, it is stated that democracy is led by wisdom in deliberation/representation. This highest value, then further elaborated in the 1945 Constitution and a number of laws and regulations under it.

The principle of negotiation for consensus is the basic value used by the disputing parties in finding a special solution outside the court. The value of consensus agreement is concrete in a number of alternative dispute resolutions such as mediation, arbitration, negotiation, facilitation, and various other forms of dispute resolution. In the history of Indonesian legislation, the principle of peaceful negotiation for consensus has also been used in the judiciary, especially in the process of resolving civil cases. This can be seen from a number of laws and regulations since the Dutch colonial era until now which still contain the principle of negotiation for consensus as one of the principles of civil justice in Indonesia.

In article 130 of HIR (Het Herziene Indonesich Reglement, Staasblad 1941:44), or article 154 of R.Bg (Reghlement Buitengewesten, Staatblad, 1927:277), or article 31 of Rv (Reglement op de Rechtvordering, 
Staatblad 1874:52), it is stated that the judge or panel of judges attempt to make peace before their case is decided. In more detail, the provisions of this article are as follows:

1. If one a specified day both parties arrive, the district court with the help of the chairman tries to reconcile them;

2. If such reconciliation can be achieved, then at the meeting, a certificate of the deed will be made regarding it, in which the latter two will be punished for keeping the agreement made. This letter will be effective and will be made as an ordinary decision;

3. Such a decision cannot be appealed; and

4. If an interpreter is needed in the attempt of reconciliation of the two parties, then the following article rules are obeyed for that (Syahrizal Abbas, 2009).

The provisions in article $30 \mathrm{HIR} / 5 \mathrm{R} . \mathrm{Bg} / 31 \mathrm{Rv}$ describe that dispute resolution through peaceful means is part of the dispute resolution process in court. Peace efforts are the responsibility of the judge. Furthermore, the judge may not decide a case before the mediation attempt has been made.

The current development indicates the public's trust in the world of justice is decreasing. Even more tragic, the community views the judiciary as being ignored. This is normal because the laws that exist in Indonesia are still far from good quality. Bureaucratic reform is considered a failure because political battles are no longer in a healthy manner. Perhaps, it is more appropriate to be considered that Indonesia is still using the 'law of the jungle.' Mediation is a very effective alternative solution for case resolution because decisions are made based on the wishes of both parties in the case who are accompanied by a mediator. This is regulated in the Supreme Court Regulation No. 1 of 2008 concerning the mediation procedure of article 2 paragraph 3. If this mediation is not carried out, the judge's decision is considered null and void.

The existence of this absolute necessity is based on legal reasons, one of which is as stated in the consideration section, which explains "that the integration of mediation into the court proceeding process can be an effective instrument to overcome the accumulation of cases in court and strengthen and maximize the function of court institution in dispute resolution in addition to court processes to be adjudicative in nature."

Furthermore, the enactment of the Supreme Court Regulation indicates that the court is proactive in conducting the mediation process. Therefore, the mediation process becomes a part of procedural law that cannot be separated from other stages of the process, such as the reading of claims, answers replications, duplications, proofs, and so on. Naturally, mediation is required to be carried out seriously both by the judge and by an individual or institution that has been certified by the Supreme Court to become a mediator. This is necessary because considering that a mediator is obliged to be able to divert the intentions of the two parties from one who wants to divorce to cancel her intention, leading the peaceful settlement for the two parties in the case.

Mediation is a very effective alternative solution for case resolution because decisions are made based on the wishes of both parties in the case who are accompanied by a mediator. A mediator is required to be able to diver the intention of the two parties from the one who wants to divorce to cancel the intention, leading to a peaceful settlement for the two parties in the case. The mediator is the judge or individual institution that has been certified by the Supreme Court.

\section{ACKNOWLEDGMENT}

A thank you to IAI Ar Risalah Guntung, STIE Galileo, STAI Ibnu Sina Batam, STAI Diniyah Pekanbaru, Universitas Islam Kuantan Singinging, STAI Auliaurrasyidin Tambilahan Inhil Riau, and partners lecturer.

\section{REFERENCES}

1. Allan J. Stit, 2004, Mediation: A Practical Guide, (London: Routledge Cavendish), 2.

2. Bambang Sutiyoso, Arbitration Law and Alternative Dispute Resolution, (Yogyakarta: Gama Media, 2008), 56.

3. Civil Code

4. http: // pn-kepanjen.go.id

5. Karmuji, Role and Function of Mediators in Civil Case Settlement (Journal of Ummul Qura Vol VII, No.1 March 2016), 36-52.

6. Nita Nurvita, Role of Mediator in Settlement of Divorce Cases at the Pekanbaru Religious Court, (JOM Faculty of Law Volume III Number 2, October 2016), 3.

7. Rachmat Syafa'at, Advocacy, and Dispute Resolution Options, Background, Concept, and Implementation, (Malang: Yayasan Pembangunan Nasional (YPN), 2006 ), 35-36.

8. Regulation of the Supreme Court of the Republic of Indonesia No 2 of 2012 regarding the adjustment of the Limits on Minor Crimes and the Number of Fines in the Criminal Code.

9. Regulation of the Supreme Court of the Republic of Indonesia No. 1 of 2008 Article 9 paragraph (3).

10. Regulation of the Supreme Court of the Republic of Indonesia No.01 of 2008.

11. Regulation of the Supreme Court of the Republic of Indonesia No.1 of 2008.

12. Susanti and Adi Nugroho, Consumer Dispute Resolution Process, in terms of procedural law and implementation constraints, (Jakarta: Kencana Prenada Media Group, 2008), 109. 
13. Suyud Margono, Alternative Dispute Resolution and Arbitrate (Bogor: Ghalia Indonesia, 2004), 63.

14. Syahrizal Abbas, Mediation (in the Perspective of Syari'ah Law, Customary Law, and National Law), (Jakarta: Kencana Prenada Media Group, 2009), 1-2, 21, 283, 288. 